\title{
THE SOCIAL IDENTITY DIMENSION OF INTER-GROUP CONFLICTS
}

\author{
MUZAFFER ERCAN YILMAZ* \\ Balıkesir University
}

\begin{abstract}
This article aims to provide an analytical discussion for inter-group conflicts in the context of the social identity phenomenon, a rather neglected dimension of social conflict. The study reveals that social identity is related to inter-group conflicts by leading to stereotyping, ethnocentric behaviors, and inter-group competitions, offering, thus, a useful framework in capturing many social-psychological aspects of these conflicts. It is noted, however, that social identity, by itself, is not a direct cause of overt inter-group conflicts. The need for further research into conditions that may tie the dynamics of social identity to expressed inter-group conflicts in a clearer way is urged.
\end{abstract}

Key words: social identity, inter-group conflict, ethnocentrism, stereotyping, inter-group relations.

\section{GRUPLAR ARASI UYUSSMAZLIKLARIN SOSYAL KIMMLIKK BOYUTU}

\section{$\ddot{O Z E T}$}

Bu makale, sosyal uyuşmazlıkların genellikle göz ardı edilen bir boyutu olan sosyal kimlikçerçevesinde, gruplar arası uyuşmazlıklara ilişkin analitik bir tartışma ortaya koymayı amaçlamaktadır. Çalışmada, sosyal kimliğin önyargılara, grup merkeziyetçiliğine ve gruplar arası rekabete yol açması nedeniyle gruplar arası uyuşmazlıklarla ilişkili olduğu, bu yüzden de bu tür uyuşmazllkların bir takım sosyopsikolojik boyutlarını kavrama bă̆lamında yararlı bir yaklaşım sunduğu belirtilmektedir. Bununla birlikte, sosyal kimliğıin gruplar arası uyuşmazlıkların doğrudan bir nedeni olmadı̆̆ına işaret edilmekte ve sosyal kimlik dinamikleri ile açık gruplar arası uyuşmazlıkları iliş̧kilendiren koşulların ileri araştırmalarla ortaya konması gereği vurgulanmaktadır.

Anahtar kelimelerr: sosyal kimlik, gruplar arası uyuşmazlık, grup merkeziyetçiliği, önyargılar, gruplar arası ilişkiler.

Sources of inter-group conflicts have been a major subject for scholarly research. As used here, the term "inter-group conflict" refers to manifested struggles between or among human groups, in their broader sense, over competing goals. The goals that groups want to achieve may include material values (e.g., land, capital, property, etc.), psychological ones (e.g., power, status, positive esteem, etc.), or often a mixture of both.

* Muzaffer Ercan Y1lmaz is an Associate Professor in the Department of International Relations at Balıkesir University, 10200, Bandırma, Balıkesir, Turkey. E-mail: muzaffer_ercan@yahoo.com 
As social beings connected to many groups, all humans experience inter-group conflicts at certain points in their lives, some indeed rather frequently, and want to avoid their destructive consequences. This is exactly what makes the subject popular. Efforts to understand and explain such conflicts have, by far, produced many competing ideas and theories. Liberal economists, for instance, have pointed to resource scarcity and inevitable competition over limited resources. Marxists, on the other hand, have blamed capitalist systems and pointed to class struggles as the main problem. Freud and his followers underlined imperfect human nature and unresolved human traumas. More recently, many conflict specialists have given more weight to basic needs, frustration and relative deprivation, while many others referred to several other factors, ranging from rapid social change to power deflation. ${ }^{(1)}$

The debates still go on and different perspectives certainly have their own usefulness in capturing different dimensions of the complex phenomenon of inter-group conflicts. The purpose of this study is to make a contribution to the continuing debate by focusing on the social identity dimension of such conflicts. Social identity has been one of the little known, and less appreciated, dimensions of inter-group conflicts. But it actually offers a useful framework to explain and understand some non-material, even apparently irrational, aspects of these conflicts. This study aims to reveal these contributions, with an ultimate aim to improve our understanding of broader human conflict.

As for the plan of the article, the study will start with an overview of social identity, dealing briefly, in this respect, with the formation process and general characteristics of the phenomenon in conjunction with human cognition. This will be followed by a more detailed discussion on the effects of social identity on inter-group relations and specifically, inter-group conflicts, supported by some real world examples as well. Based on the discussion, the areas that need further exploration will also be addressed in order possibly to guide the directions of future research on the subject.

\section{SOCIAL IDENTITY: AN OVERVIEW}

According to the Oxford English Dictionary, the term identity has a Latin root (identitas, from idem, "the same") and two basic meanings. The first is a concept of absolute sameness: that is, this is identical to that. The second is a concept of distinctiveness, which presumes consistency or continuity over time. Approaching the idea of sameness from two different angles, the notion of identity simultaneously establishes two possible relations of comparison between persons or things: similarity, on the one hand, and difference, on the other.

One significant component of individual identity is social identity. The expression refers to the ways in which individuals and collectivities are distinguished in their social relations with other individuals and collectivities (Jenkins, 2004: 4). It is the systematic establishment and signification between individuals, between collectivities, and between individuals and collectivities, of the relationship of similarity and difference. Taken together, similarity and difference appear to be the dynamic principles of social identity.

As we learn from psychoanalytic child researchers, no one has a separate sense of self in early life no matter how much potential and ability an infant possesses. Identity, or the cohesive sense of self, begins to be formed slowly during the childhood period by the child's accumulation and internalization of in-group norms shaped by the adults in that group. Such transmission is not simply from the child's hearing stories, reading books, etc. It occurs mostly in a silent fashion through the media of parental 
stories, communal festivals, formal education (socialization), as well as through the child's relationship with important figures in the group (identification) (Rayner, 2005; Cote, 2006).

Once formed, social identity becomes rather difficult to change, since the individual sense of self and social identity are inherently intertwined. That is why any radical change in a formed identity may be equal to, to use Volkan's term, "psychological death" for individuals (Volkan and Itzkowitz, 1994: 15). Death, here, may be a little exaggerated, but it is true that changes in established identities severely disturb individuals as they deeply shake their inner security. Indeed, the self-esteem of individuals often rises and falls with the fate of their group. A success of an in-group uplifts the individuals in that group and a failure hurts them (Haslam, 2001).

Of course, the general characteristic of the rigidity of social identity is not to argue that established identities do not change at all. Individuals are social beings and they engage in countless social interactions throughout their lives. The ongoing social interactions may re-define formed social identities and even add new ones. But nonetheless, the primary identifications of selfhood, gender and, under certain circumstances, kinship and ethnicity are very deep-rooted; therefore, generally speaking, they are more resistant to change (Davis, 2000).

It should also be noted that the intensity of feelings with respect to different social identities may vary depending on personal and cultural traits. Some individuals may feel strong self-attachments to certain groups, while some others may not. Likewise, in some cultures, ethnic identity would be the most powerfully felt social identity, but in others, it would be religious or gender identity. In Western cultures, for example, narrowly-defined, blood-based ethnic identity is rarely observed. As D. L. Horowitz explains in his classical study, Ethnic Groups in Conflict, a number of historical developments unique to the Western world, the Reformation, the Enlightenment and the Industrial Revolution have brought about an overarching layer of ethnic identity, as well as other forms of group difference (e.g., class, gender), while ethnicity based on blood relationship has remained strong in the non-Western world where no such developments did occur, at least in the way they occurred in the West (Horowitz, 1985: 19-20; see also Weedon, 2004).

Although such varieties occur, possessing a social identity, indeed many social identities, is common to all people and this does not just result from a simple learning process. Social interactions certainly affect social identities in terms of shaping their content, but the essence of them is rooted in three basic psychological needs that are shared by all humans. First, human social life is unimaginable without some sense of who others are and some sense of who we are. That is, social identity provides a "cognitive map" for humans to locate themselves in complex social interactions and clarify their position in them (Allen, 2004). As a matter of fact, one of the first things we do when we meet strangers is to place them on our social maps, to "identify" them (Haslam, 2003). Second, membership of some larger collectivity or grouping satisfies an intense desire to belong, to be accepted by other people. Therefore, identification and acceptance lessen a sense of isolation for individuals. Related to that, finally, by belonging to a group, or groups, individuals attempt to get rid of the psychological burden of individual weaknesses. Group identification reduces uncertainty, fear and anxiety with respect to real-life problems, and increases the inner security of individuals (Abrams and Hogg, 1999; Petersson and Clark, 2003). 


\section{SOCIAL IDENTITY AND INTER-GROUP RELATIONS: IMPLICATIONS FOR INTER-GROUP CONFLICTS}

Once an individual has identified himself or herself with a group, sharing that group's values, beliefs and attitudes, a number of "follow-up" psychological processes occur, which can be summarized as follows:

\section{Cognitive Discrimination and Stereotyping}

Since identification with a particular collectivity or group means an increasing self-esteem and inner security, it is preferable that the group is seen to possess desirable qualities in its own terms and in the terms of the individual group member. Individuals would like to be identified with a grouping which appears worthy in terms of their own values (Turner, 1975; Turner and Brown, 1978). Of course, many individuals cannot choose their own groupings, but they belong to ascribed categories. This is typically the case for ethnic or national identity. Few individuals can actually choose their own national groupings. However, a common tendency for individuals in ascribed membership groupings is to emphasize the desirable qualities of their groups to themselves.

The tendency to avoid thinking badly about one's own group is related to an individual's desire to think well of himself or herself. If the group is regarded as an extension of the individual, it follows that each member would like to be perceived as possessing desirable qualities and behaving in a worthy manner (Mitchell, 1998: 87).

This tendency, in turn, inevitably leads to in-group centrality and discrimination against out-groups, which best manifest themselves in group stereotypes. Stereotypes, as used here, refer to a set of beliefs that a group is convinced are valid. Group members, in this regard, attribute desired qualities to themselves and unwanted ones to other groups. They view themselves as good, successful, honest, virtuous and peace-loving, while seeing out-group members with opposite terms, as evil, lazy, deceptive, bellicose and so on (see, Stangor, 2000).

Such negative stereotypes are mostly based on beliefs rather than reality, and are rooted in the psychological and social-psychological process of "projection." That is, group members simply project their unwanted aspects on relevant out-groups in order to "purify" their group and keep the "good" for themselves (Gemmill, 1998).

Having said that, it is the case at times that the origin of stereotypes is based on some real events; that is, out-groups may have actually harmed the in-group in the past (Lee et al., 1995), but still stereotypes reflect heavily-mythologized, exaggerated and subjectively-evaluated events. Once formed, they quickly become a part of a group identity, shaping deeply each group member's perspective. From that time on, reality does not actually matter. Out-group members are seen and evaluated through the stereotypical lens with respect to past and present (Wendy, 2006).

Apart from cognitive discrimination, stereotypes harm inter-group relations in a number of ways, summarized as follows:

Selective Perception. Because of stereotypes, groups tend to see and acknowledge negative aspects of each other that fit or support the stereotype and ignore other aspects that do not fit. In other words, they 
see what they want to see and overlook what they wish to ignore. As a result of this black-and-white cognition, "de-individualization" takes place, a collectivist ethic emerges, and polarization becomes easier (Mitchell, 1987: 113; Y1lmaz, 2005: 5-6).

Self-Fulfilling Prophecy. The perception of out-groups, even if it is erroneous, helps to shape reality and brings on the self-fulfilling prophecy. Especially when suspicions run high or inter-group conflict occurs, a defensive move by one side may look provocative to the other, evoking from the latter a further defensive reaction that serves only to confirm the suspicions of the former. Similarly, group members tend to be aggressive towards out-group members that they view as hostile, which, in turn, leads out-groupers to retaliate, hence confirming the view of them as hostile (Mitchell, 1987: 115; Y1lmaz, 2005: 6).

Biased Attribution. When an out-group behaves the way that a group expects, the group tends to attribute that behavior to the out-group's inner dispositions, reinforcing its view of what the out-group is really like. When the out-group behaves differently from the expectation of the group, on the other hand, the group mostly attributes that behavior to the out-group's weaknesses, rather than its good will (Allison and Messick, 1985).

At the international level, that was particularly the case in American-Soviet relations during the Cold War era. That is, when the Russians behaved contentiously, the American government announced that this confirmed the Russians' "aggressive nature". When the Russians behaved in a conciliatory fashion, the American government, in that case, explained that behavior as due to circumstances such as military weakness. This way, the Americans maintained a stable view of the Soviet Union throughout the Cold War (Stagner, 1967).

Mirroring. Stereotypes are also mirrored; that is, so long as a group possesses certain negative images regarding an out-group, the out-group retaliates in the same way and develops similar images, even if it does not have any in the beginning. Over time, both sides become equal in terms of having polarized images which are, indeed, quite analogous.

For example, in a cultural study of Jewish-Arab attitudes, Raymond Cohen found that two-thirds of the Jews thought that they could not trust the Arabs, and similarly, two-thirds of the Arabs thought that they could not trust the Jews (Quoted in Ryan, 1995: 87-88). Similarly, in November 1989, ICAP and PIAR, two major public relations firms from Greece and Turkey, which carried out a joint poll in order to measure the public views, found that the Greeks and Turks almost equally mistrusted each other, with 81 percent of the Greeks and 80 percent of the Turks suspicious of the other (Volkan and Itzkowitz, 1994: 167).

Dehumanization. Lastly, dividing people into "us" and "them" almost inevitably involves some degree of down-grading of out-groups so that groups can be satisfactorily up-graded. Experimental work by $\mathrm{H}$. Tajfel indicates that even the mere act of dividing individuals into categories on some quite arbitrary basis is sufficient to begin processes of evaluating aspects of "our" group much more positively than "theirs," and that there exists a generic norm of out-group behavior which is discriminative, irrespective of the nature of the groups in question (Tajfel, 1970). 
A more extreme form of down-grading of out-groups manifests itself in a dehumanization process. Dehumanization can be characterized by a decline in empathy for out-group members and involves the removal of human facets. Empirical evidence suggests that especially in situations of intense conflict, a psychological need for dehumanization arises, since violence and brutal tactics targeting out-groups cannot be easily justified otherwise. For instance, before the Japanese performed medical experiments on some Chinese in World War II, they named them maruta- logs of wood (Keen, 1986: 25). Likewise, when Western countries went to war against the Asians, they often portrayed them as "faceless hordes, as alike as photo-prints from the same negative" (Keen, 1986: 26). More recently, we have all witnessed, thanks to global communication, how some Iraqi prisoners were dehumanized and tortured by many American and British soldiers.

Dehumanization, as a result, systematically destroys the individual's tendency to identify himself or herself with other human beings, and provides him or her with an emotional ground for cruel acts, even killing. Therefore, negative stereotypes do not only involve feelings of dislike but also may breed violence under conditions of large-scale, intense conflicts.

\section{Tendency to Preserve Group Unity Against External Threats}

Aside from stereotyping and downgrading of out-groups, group members are also motivated to preserve group cohesion against real or perceived external threats posed by out-groups, mostly in an exaggerated way. External threats, as used here, refer to unwanted influences of out-group norms, as well as physical interventions by, or domination of, out-groups.

In this respect, it is a general tendency for groups to react to out-group norms with a feeling of dislike, and to be motivated to protect their in-group ones against them. This way, they aim to preserve group purity and, with the self-attachment to the group, self-purity ultimately.

This tendency seems to be more evident in traditional societies where religion, ethnicity, family and sub-culture in general play a significant role in the life of an average individual. The concern to preserve in-group values against outside influences may manifest itself in a variety of ways, ranging from non-violent intolerance to violent intolerance. This usually depends on the degree of perceived external threats. In general, the greater the external threats, the more likely the reaction against out-groups will be violently intolerant. There are some studies to suggest that violent actions in many Muslimpopulated counties against tourists, bars and night-clubs, perceived as symbols of Western culture, are related, among other reasons, to the concern for preserving in-group purity (Barsalou, 2002; Davidson, 2003). At times, this concern would even be translated into what is called "religious fundamentalism" as the movement eagerly values traditional in-group norms and expresses a rigid dislike towards outgroup ones, also promising the public that it will get rid of the "offending values" when its political power is obtained (Y1lmaz, 2002).

The concern for preserving group unity often takes a more activist turn when a group faces direct physical intervention or domination by out-groups. Such threats are certainly more palpable and greater than normative threats and usually trigger in-group defense using all means, including violence. The fact that people may be willing to die instead of accepting out-group domination during wars or civil wars can perhaps be understandable in this context (Volkan, 2004; Sen, 2006). 
When there is an overt power disparity between conflicting groups, the powerful group may be able to dominate the weak one in the short run. The group whose subordinate status is maintained through repression usually nurtures deep grievances against the dominant group, but would be hesitant to act on it so long as its impotent position continues. But it eventually takes action when conditions start to favor itself and disfavor its opponent (Gurr and Davies, 2002:32-34). This explains, at least in part, the pervasiveness of independence struggles in Asia and Africa against powerful Western counties after the Second World War, as well as many ongoing intra-state conflicts in the post-Cold War era in which the legitimacy of dominant groups and their state is under question (Gurr and Davies, 2002; Y1lmaz, 2006).

\section{Unfavorable Inter-Group Comparisons}

A final social identity related dimension of inter-group conflicts is unfavorable group comparisons. That is, groups constantly compare themselves to similar out-groups to get an idea of "how they are doing," so as to evaluate their relative position and success. When the results of these comparisons are unfavorable, group members tend to become conflict-prone against relevant out-groups that are in $\underline{\text { a }}$ better position.

The scientific discovery of social comparisons as a common phenomenon in human relations started with Leon Festinger's keen observations in the early 1950's. Festinger realized that individuals constantly evaluate their opinions and abilities by comparing them to the opinions and abilities of other people. In order to do that, they chose similar others with whom to compare themselves as well. These two behavioral dynamics common to all people led Festinger to develop his famous "social comparisons theory" in the mid-1950s (Festinger, 1954).

This theory was later transferred to the group context and inter-group relations by H. Tajfel and J. C. Turner in the mid-1970s at Bristol University, UK, becoming the core of the social identity theory. Many of the concepts of the social identity theory are similar to those of the social comparison theory, but the social identity theory makes its unique contributions in considering social comparison on a between-groups or inter-group basis, rather than on a within-groups or inter-personal basis (Turner, 1975; Tajfel and Turner, 1986).

The basic idea (of the social identity theory) is that like individuals, groups, too, continually compare themselves to other similar groups. Because social identities have significant self-evaluative consequences, group members are first motivated to adopt strategies for achieving or maintaining inter-group comparisons that favor the in-group and thus the self (Tajfel and Turner, 1986; Tesser, 1998). That is, they subjectively want to see their in-group superior in relation to relevant out-groups. Despite this tendency, sometimes the superiority of out-groups, in general or in specific areas, would be so evident that it cannot be subjectively denied. In such cases, group members experience a negative social identity, meaning they feel inferiority for their group and because of the self-attachment to the group, for themselves.

Individuals experiencing negative social identity can theoretically leave their group and become attached to more prestigious ones. But in reality, leaving the group is psychologically so costly that it rarely happens. The reason for this is that first of all, after a long time of sharing, the individual develops deeply rooted personalized ties with his or her group. Hence, leaving the group may harm 
his or her sense of self and may cause a sense of insecurity. That aside, the group, too, can impose a number of sanctions on the individual. Exclusion or isolation of the "deviant individual" (a cutting off the communication and then membership) is one obvious reaction. Other sanctions would be the physical ones imposed by the threat, or fact, of bodily harm, or loss of some property. But the most effective group sanctions operate more subtly. The mere psychological stress of being isolated from the group is often enough to make the individual remain in his or her own group (Mitchell, 1998: 8990).

Accordingly, the high cost of leaving the group gives group members experiencing negative social identity another option: making their group better in weaker areas so that they can become compatible and desirably equal to relevant out-groups. This, indeed, is the way that group members can truly overcome unfavorable inter-group comparisons and the related sense of group inferiority. However, making the group better frequently causes in-group members to engage in a harsh competition with members of similar out-groups. Thus, competition among groups can be, indeed often is, motivated as much by the self-evaluation needs of group members as by a real conflict of interests (conflict over scarce resources). Groups are more likely to compete and discriminate against out-groups that are in some way comparable or salient (Turner and Brown, 1978). If comparisons continue to be unfavorable and social identity is severely threatened, despite efforts to close the gap with relevant out-groups in better position, group members may become more conflict-prone against them so as to break their powerful position.

\section{APPLICATIONS OF SOCIAL IDENTITY APPROACH TO SOME REAL WORLD CASES AND CONCLUSION}

As the above discussions attest, the social identity approach offers a useful framework in capturing some hidden and "irrational," so to speak, dimensions of inter-group conflicts. The contributions also reveal a challenge to the common knowledge of inter-group conflicts that often ties them to resource competition, class struggle, imperfect human nature and that kind of classical explanation.

Yet in this article, it is posited that without a real conflict of interest, social identity itself almost inevitably involves cognitive discrimination, stereotyping and down-grading of out-groups, which breed overt or covert inter-group conflicts. To give some examples at the macro level, throughout the Cold War, the Soviet leadership perceived the United States as an "imperial enemy." The Chinese leaders have at times stereotyped others as "barbarians." Iran, since Ayatollah Khomeini, has often described western leaders as "degenerates." Likewise, the United States saw the Soviet Union during the Cold War as an "evil element" and governments in Eastern Europe as its mere puppets. Arabs tend to see Israel as an extension of either Western colonialism or American imperialism. Many other examples could be cited. Even if there exists a certain degree of truth in such group stereotypes, they are, nonetheless, mostly products of belief systems rather than reality, and are well embedded within a larger social identity.

Another relevance of the social identity approach to inter-group conflicts, as addressed in this article, is that because the sense of self and in-group(s) are interconnected, group members are motivated to defend their group unity and their perceived group superiority against external threats. External threats would involve unwanted influences of out-group norms, as well as domination by out-groups. Depending on the real or perceived scope of external threats, the motive to defend in-group unity may take the form of violent intolerance. There were numerous widely publicized examples in past years. 
Among them are the bombing of the New York Trade Center by Islamic militants, even the September 11, 2001 attacks, the massacre by a Jewish zealot of two dozen Muslim worshippers in Hebron, the explicit blessing of violence by both Serbian Orthodox and Croatian Catholic Christians in the conflict in the former Yugoslavia, and the ongoing attacks by Iraqi guerillas against coalition forces, namely US forces and their supporters. In all these examples, groups or nations, generally believed that they were right, and large-scale violence was obligatory to meet the "great threat" posed by their enemy.

Finally, the social identity approach reveals that as in the interpersonal context, social comparisons also occur within the group context. In order to evaluate their positions, groups make comparisons to other similar groups. If comparisons are favorable, group members obtain a positive social identity, thus, a positive self-esteem. If not, they experience a negative social identity, thus, a low level of selfesteem. Group members experiencing negative social identity usually become conflict-prone against out-groups that are in better positions. This can especially be observed in most ethnically-driven conflicts of the post-Cold War era. Obvious inequalities in status and well being cause deep grievances for underprivileged ethnic groups in multi-ethnic states. Even if there is no legal restriction for upward social mobility, minority people are mostly entrapped in underprivileged conditions and very few can actually get ahead in the system. The discontent regarding their disadvantages in comparison with privileged groups often becomes the motive for political mobilization. Many minority groups' protests and even the rebellion of some in France about two years ago, the hidden tension between White and non-White Americans, and between the Black and White in South Africa do not seem to be independent of this kind of structural discrimination. The perception of limited possibilities for upward social mobility tends to anger and motivate minority groups to utilize conflict as a means to obtain what the privileged groups have.

However, these points should not be understood to imply that social identity phenomenon is a direct cause of inter-group conflicts. If it did, such conflicts would occur at all times, under all conditions. But we know that this is not the case in reality. While the dynamics of social identity may create conditions that breed inter-group antagonism as summarized above, it is still ambiguous why relationships among some groups are much more competitive and conflict-prone than among others. Likewise, it is not clear why self-group centrality and in-group favoritism precipitate violent conflicts in some situations, but not in others. Finding satisfactory answers to such fundamental questions begs for further exploration

\section{NOTE}

1. For a good summary of the classical theories of social conflict, in general, and inter-group conflict in particular, see Jeong (20002), Barash (2002), Webel (2002), and Pruit et al. (2004)

\section{REFERENCES}

Abrams, D. and Hogg, M.A. (1999). Social Identity and Social Cognition. Malden, Mass: Blackwell.

Allen, B.J. (2004). Difference Matters. Long Grove, II: Waveland Press.

Allison, S. T. and Messick, D. M. (1985). “The Group Attribution Error,” Journal of Experimental Social Psychology, (2): 563-579.

Barash, D. and Webel, C. (2002). Peace and Conflict Studies. London: Sage Publications. 
Barsalou, J.M. (2002). Islamic Extremists: How Do They Mobilize Support? Washington, DC: US Institute of Peace Press.

Cote, J.E. (2006). “Acculturation and Identity: The Role of Individualization Theory," Human Development, (49): 31-35.

Davidson, L. (2003). Islamic Fundamentalism: An Introduction. Westport, Conn.: Greenwood Press.

Davis, J.E. (2000). Identity and Social Change. New Brunswick, NJ: Transaction Publishers.

Festinger, L. (1954). “A Theory of Social Comparison Processes,” Human Relations, (7): 117-140.

Gemmill, G. (1998). "The Dynamics of Scapegoating in Small Groups," Small Group Behavior, (20): 406-418.

Gurr, T.R. and Davies, J. (2002). "Dynamics and Management of Ethnopolitical Conflicts," in J. Davies and E. Kaufman (eds.), Second Track/Citizen's Diplomacy: Concepts and Techniques for Conflict Lanham, MD: Rowman and Littlefield.

Haslam, A.S. (2001). Psychology in Organizations: The Social Identity Approach. London: Sage Publications.

-----, (2003). Social Identity at Work. New York: Psychology Press.

Horowitz, D.L. (1985). Ethnic Groups in Conflict. Berkeley: University of California Press.

Jenkins, R. (2004). Social Identity. $2^{\text {nd }}$ ed. London and New York: Routledge.

Jeong, H. (2002). Peace and Conflict Studies: An Introduction. Aldershot: Ashgate Publishing.

Keen, S. (1986). Faces of the Enemy. San Francisco, CA: Harper Collins.

Lee, Y.T., Jussim, L.J., and McCauley, C.R. (1995). Stereotype Accuracy. Washington, DC: American Psychology Association.

Mitchell, C.R. (1998). The Structure of International Conflict. New York: St. Martin’s Press.

Petersson B. and Clark E. (2003). Identity Dynamics and Construction of Boundaries. Lund, Sweden: Nordic Academic.

Pruitt, D.G., Kim, S.H., and Rubin, J.Z. (2004). Social Conflict: Escalation, Stalemate, and Settlement. $3^{\text {rd }}$ ed. New York: McGraw-Hill.

Rayner, E. (2005). Human Development: An Introduction to the Psychodynamics of Growth, Maturity and Ageing. New York: Routledge. 
Ryan, S. (1995). Ethnic Conflict and International Relations. Brookfield, Vermont: Dartmouth Publishing Com.

Sen, A.K. (2006). Identity and Violence. New York: W.W. Norton and Co.

Stagner, R. (1967). The Dimensions of Human Conflict. Detroit: Wayne State University Press.

Stangor, C. (2000). Stereotypes and Prejudice: Essential Readings. Philadelphia, PA: Psychology Press.

Tajfel, H. (1970). “Experiments in Inter-Group Discrimination,” Scientific American, (223): 96-102.

Tajfel, H. and Turner, J.C. (1986). “The Social Identity Theory of Inter-Group Behavior,” in W.G. Austin and S. Worchel (eds.), Psychology of Inter-Group Relations: 7-24. Chicago: Nelson-Hall Publishers.

Tesser, A. (1988). “Towards a Self-Evaluative Maintenance Model of Social Behavior,” in L. Berkowitz (ed.), Advances in Experimental Social Psychology, (21): 181-227. Orlando, FL: Academic Press.

Turner, J.C. (1975). "Social Comparison and Social Identity: Some Prospects for Inter-Group Behavior," European Journal of Social Psychology, (5): 5-34.

------, (1985). "Social Categorization and The Self Concept: A Social Cognitive Theory of Group Behavior,” in E.J. Lawler (ed.), Advances In Group Processes: Theory and Research, (2): 77-121. Greenwich, CT: JAI Press.

Turner, J.C. and Brown, R.J. (1978). "Social Status, Cognitive Alternatives and Inter-Group Relations," in J.C. Turner (ed.), Differentiation Between Social Groups: Studies in The Social Psychology of InterGroup Relations: 202-234. London: Academic Press.

Volkan, V.D. and Itzkowitz, N. (1994). Turks and Greeks: Neighbours in Conflict. Cambridgeshire, England: The Eothen Press.

Volkan, V.D. (2004). Blind Trust. Charlottesville, VA: Pitchstone Publishing.

Weedon, C. (2004). Identity and Culture. New York: Open University Press.

Wendy, L.H. (2006). From Generation to Generation: Maintaining Cultural Identity Over Time. Cresskill, NJ: Hampton Press.

Yılmaz, M.E. (2002). "Religious Revivalism in the Social Identity Context." Ph.D. Dissertation, George Mason University, Fairfax, VA, USA.

-----, (2005). “Enemy Images and Conflict,” İstanbul Üniversitesi Siyasal Bilgiler Fakültesi Dergisi, 32(1): $1-12$.

------, (2006). “Soğuk Savaş Sonrası Dönemde Sınır İçi Etnik Çatışmalar,” Uluslararası Hukuk ve Politika, (6): 17-30. 